\title{
Aneuploid spermatocyte frequency in domestic sheep heterozygous for three Robertsonian translocations
}

\author{
A. N. Bruère, I. S. Scott and L. M. Henderson \\ Department of Veterinary Clinical Sciences, Massey University, Palmerston North, \\ New Zealand
}

\begin{abstract}
Summary. In an analysis of the chromosomes in 332 metaphase II figures from 3 triple heterozygous rams $\left(51, x y, t_{1} t_{2} t_{3}\right)$ and a further 84 figures from 3 normal rams $(54, x y)$, there were no hypermodal cells in the normal rams but 9 such cells were found in the triple heterozygotes, giving a mean aneuploid frequency of $5.42 \%$ which was similar to the levels previously found in the single heterozygotes. Forty hypomodal cells were found in the 6 rams of which a number would have lost chromosomes due to lagging at anaphase I. Individual variation in the aneuploid metaphase II frequency was observed in the triple heterozygotes.

A significant surplus of secondary spermatocytes of normal karyotype and a deficit of $25, t_{1} t_{3}$ were found in the metaphase II figures from the triple heterozygotes. There was also a significant increase of normal progeny and a deficit of $52, t_{1} t_{3}$ and $53, t_{2}$ progeny from the matings of triple heterozygous rams and normal ewes. It is possible that the significantly uneven distribution of segregation products in the triple heterozygotes might have been the result of either cell selection or degeneration during spermatogenesis.
\end{abstract}

\section{Introduction}

Extensive studies have been made on the high frequency of centric fusions (Robertsonian translocations) in several species of animals (Bruère, 1974b). From one such study there is little or no evidence to suggest that the centric fusions have any significant effect on the reproductive fitness of translocation-carrying sheep (Bruère, 1974a; Bruère \& Chapman, 1974; Bruère \& Ellis, 1979). Although significant levels of hypermodal secondary spermatocytes have been found in single heterozygous rams $\left(t_{1}, 5.63 \% ; t_{2}, 4.5 \% ; t_{3}, 9.2 \%\right.$, Chapman \& Bruère, 1975; $6.1 \%$ in $t_{1}$ only, Long, 1978), it is believed that these cells do not mature into aneuploid gametes.

From the mating studies with the single translocation heterozygous sheep no unequal number of progeny of the various segregation categories was recorded consistently. However, a significant excess of non-translocation-carrying secondary spermatocytes was found in meiotic studies of the singly heterozygous rams (Chapman, 1974; Chapman \& Bruère, 1975; Long, 1978). The studies on the tobacco mouse hybrid suggest that the effect of multiple heterozygosity would be to increase the aneuploid frequency significantly above that of the single heterozygotes. Therefore, if the same effect should be found in the ram an aneuploid frequency significantly above that of single heterozygotes would be expected in the triple heterozygotes. Variations in the levels of aneuploid secondary spermatocyte frequency have been reported in the tobacco mouse (Cattanach \& Moseley, 1973) and in sheep (Chapman \& Bruère, 1975) with different centric fusions. However, unlike sheep, the high levels of aneuploidy in the tobacco mouse hybrids are consistent with high frequencies of zygotic loss and reduction of fertility of 
the $F_{1}$ animals (Gropp, Tettenborn \& Von Lehmann, 1970; Cattanach \& Moseley, 1973). It has also been reported that the aneuploid secondary spermatocytes of one translocation-carrying strain of mice did not appear to form viable gametes (Baranov \& Dyban, 1976).

Although the significance of centric fusions and their method of formation is not fully understood (John \& Freeman, 1975; Kurnit, Brown \& Maio, 1978) it would appear that their effect on the fertility is species-specific. The present report describes chromosomes of the $F_{1}$ animals from the breeding of triple heterozygous rams and normal ewes. It also examines the individual variations in the level of aneuploid metaphase II frequency in the spermatocytes of normal and triple heterozygous rams.

\section{Materiais and Methods}

The three triple heterozygous rams used were derived from the mating experiments reported previously (Bruère \& Ellis, 1979). The karyotypes of the rams were determined by a whole blood leucocyte technique (Bruère \& McLaren, 1967) and testicular material was obtained from testes after surgical castration under local anaesthesia. The meiotic preparations were made using the technique developed for the ram by Chapman (1974). The meiotic preparations were stained with aceto-orcein for 2-3 h or with Giemsa for 10-15 min. Samples were also taken from the testes for histological examination. The sections were cut at $5 \mu \mathrm{m}$ and stained with haematoxylin and eosin. As described previously (Chapman \& Bruère, 1975) ambiguity can occur in counting metaphase II chromosomes because of their contracted nature. All chromosome arms were counted as well as the chromosome number. Acrocentric chromosomes were counted as having one chromosome arm, while metacentrics and submetacentrics were counted as having two chromosome arms. The $\mathrm{X}$ and the $\mathrm{Y}$ chromosomes were both counted as having one chromosome arm, although the latter chromosome is submetacentric.

The haploid chromosome complement for the sheep consists of 23 acrocentrics, 3 metacentrics and one sex chromosome, a total of 27 chromosomes or 30 chromosome arms.

The haploid number for the secondary spermatocyte of a normal ram was scored as $27 \mathrm{X} / 30$ or $27 \mathrm{Y} / 30$; euploid secondary spermatocytes were $\mathrm{NF} / 2=30$, and aneuploid secondary spermatocytes had an NF/2 of $>$ or $<30$.

Three estimates of aneuploid frequency were made, two were based on the method of Cattanach \& Moseley (1973). The first estimate gave the total proportion of cells with 29 or 31 chromosome arms, and the second was calculated by doubling the frequency of cells with a chromosome arm count of 31 . Because of technical factors there are always more hypomodal cells than hypermodal cells so that the former frequency is an overestimate of the number of aneuploid secondary spermatocytes. The latter is probably more correct.

A third estimate of aneuploid frequency was made by using the following formula: $\sum 29,31$ classes $\times 100 / \sum 29,30,31$ classes.

Between 1975 and 1979 our breeding programme with translocation-carrying sheep involved mating triple heterozygous rams to ewes with a normal karyotype, $2 n=54$. The karyotypes of the progeny were determined from leucocyte blood cultures.

\section{Results}

An analysis was carried out on 84 secondary spermatocytes from 3 normal rams and 332 secondary spermatocytes from 3 triple heterozygous rams (Table 1; P1. 1, Figs 1-4). For comparison with the spermatocytes from the triple heterozygotes the 84 spermatocytes from the normal rams were combined with 62 spermatocytes from normal rams previously reported (Chapman \& Bruère, 1975) and 99 spermatocytes from $t_{1} t_{1}$ rams and 23 spermatocytes from 


\section{PLATE 1}
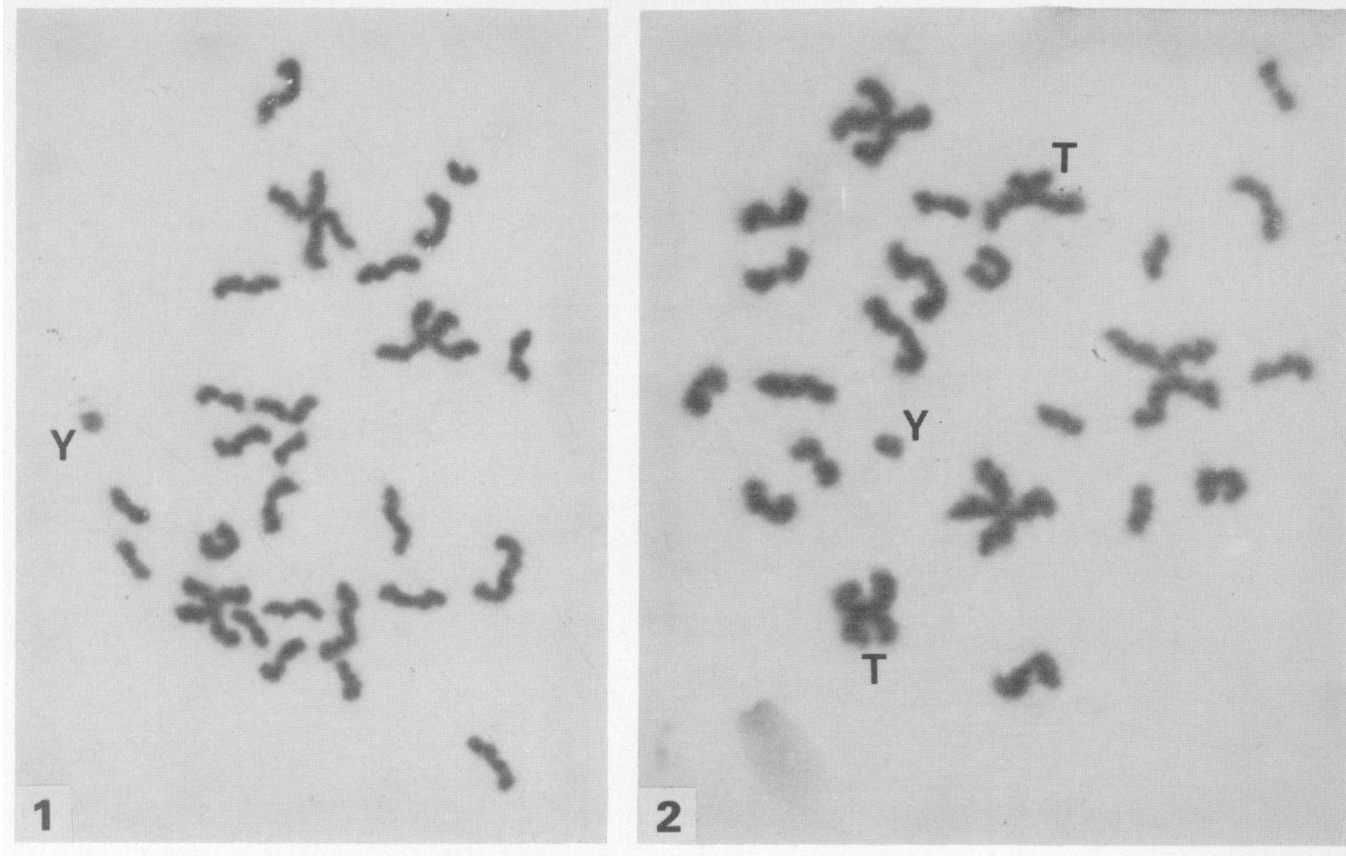

3

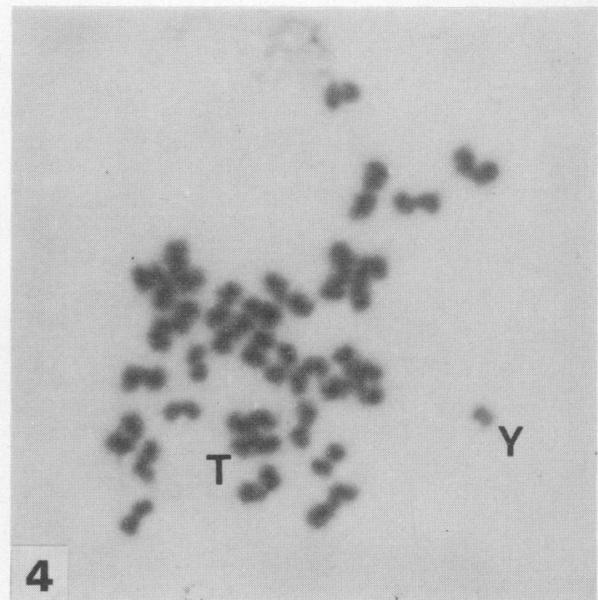

Fig. 1. Metaphase II cell with 30 chromosome arms and 27 chromosomes, including 3 metacentrics and a $\mathrm{Y}$ chromosome.

Fig. 2. Metaphase II cell with 30 chromosome arms and 25 chromosomes, including 2 translocation ( $\mathrm{T})$ chromosomes $\left(\mathrm{t}_{2} \mathrm{t}_{\mathrm{x}}\right)$ and a $\mathrm{Y}$ chromosome.

Fig. 3. Metaphase II cell with 30 chromosome arms and 24 chromosomes, including 3 translocation $(\mathrm{T})$ chromosomes $\left(\mathrm{t}_{1} \mathrm{t}_{2} \mathrm{t}_{3}\right)$ and an $\mathrm{X}$ chromosome.

Fig. 4. Metaphase II aneuploid cell with 31 chromosome arms and 27 chromosomes, including a translocation (T) metacentric and a Y chromosome. 
$\mathrm{t}_{3} \mathrm{t}_{3}$ rams. As described (Chapman \& Bruère, 1975) no hypermodal cells were observed in 268 cells from the normal rams or the homozygous translocation-carrying rams. However, 9 aneuploid (hypermodal) cells were observed in the triple heterozygotes.

Table 1. Distribution of euploid $(\mathrm{NF} / 2=30)$ and aneuploid $(\mathrm{NF} / 2<$ or $>30)$ metaphase II figures in normal and triple heterozygous rams $51, x y, t_{1} t_{2} t_{3}$

\begin{tabular}{llccrrrrr}
\hline & & \multicolumn{8}{c}{ NF/2 } \\
\cline { 3 - 9 } Karyotype & Ram & $<28$ & 28 & 29 & 30 & 31 & $>31$ & Total \\
\hline 54, xy & B51/79 & 0 & 1 & 0 & 53 & 0 & 0 & 54 \\
& A1/79 & 1 & 1 & 0 & 8 & 0 & 0 & 10 \\
& A2/79 & 0 & 0 & 1 & 19 & 0 & 0 & 20 \\
51, xy $_{1} \mathrm{t}_{1} \mathrm{t}_{2} \mathrm{t}_{3}$ & $\mathrm{~B} 47 / 78$ & 0 & 1 & 4 & 80 & 1 & 0 & 86 \\
& B 101/78 & 0 & 0 & 3 & 79 & 1 & 0 & 83 \\
& B111/77 & 2 & 6 & 20 & 128 & 7 & 0 & 163 \\
\hline
\end{tabular}

The aneuploid spermatocyte frequencies of the individual rams were analysed and are given in Table 2 and the combined data are presented in Table 3. The mean aneuploid frequency $31 \times 2(\%)$ for the three $51, x_{y}, t_{1} t_{2} t_{3}$ rams was $5.42 \%$. In the metaphase II cells of the $51, x y, t_{1} t_{2} t_{3}$ rams the X chromosome was present in 162 cells and the $Y$ chromosome in 163 cells, while $41 \mathrm{X}$ bearing cells and $42 \mathrm{Y}$ bearing cells were seen in the metaphase II figures of the normal rams. In neither case does this depart from the expected ratio.

Table 2. Aneuploid frequencies for the normal and triple heterozygous rams

\begin{tabular}{llccc}
\hline \multirow{2}{*}{ Karyotype } & Ram & $29+31(\%)$ & $31 \times 2(\%)$ & $\frac{\sum 29,31 \text { classes }}{\sum 29,30,31 \text { classes }} \times 100 \%$ \\
\hline $54, \mathrm{xy}$ & $\mathrm{B} 51 / 79$ & 0.00 & 0.00 & 0.00 \\
& $\mathrm{~A} 1 / 79$ & 0.00 & 0.00 & 0.00 \\
& $\mathrm{~A} 2 / 79$ & 5.00 & 0.00 & 5.00 \\
$51, \mathrm{xy}, \mathrm{t}_{1} \mathrm{t}_{2} \mathrm{t}_{3}$ & $\mathrm{~B} 47 / 78$ & 5.81 & 2.33 & 5.88 \\
& $\mathrm{~B} 101 / 78$ & 4.82 & 2.41 & 4.82 \\
& $\mathrm{~B} 111 / 77$ & 16.56 & 8.59 & 17.42 \\
\hline
\end{tabular}

Table 3. Aneuploid frequencies for the normal single translocation-carrying rams $\left(53, x y, t_{x}\right)$, homozygous $\left(52, x y, t_{1} t_{1}\right.$ and $\left.52, x y, t_{3} t_{3}\right)$ rams and triple translocation-carrying rams $\left(51, x_{1}, t_{1} t_{2} t_{3}\right)$

\begin{tabular}{|c|c|c|c|c|c|}
\hline Karyotype & $\begin{array}{l}\text { No. of } \\
\text { rams }\end{array}$ & $\begin{array}{l}\text { Total no. } \\
\text { of cells }\end{array}$ & $29+31(\%)$ & $31 \times 2(\%)$ & $\frac{\sum 29,31 \text { classes }}{\sum 29,30,31 \text { classes }} \times 100 \%$ \\
\hline$\uparrow 54, x y$ & 13 & 146 & 2.74 & 0.00 & 2.94 \\
\hline$* 52, x y, t_{1} t_{1}$ & 1 & 99 & 6.06 & 0.00 & 6.59 \\
\hline$* 52, x y, t_{3} t_{3}$ & 1 & 23 & 8.70 & 0.00 & 8.70 \\
\hline$* 53, x y, t_{1}$ & 6 & 160 & $26 \cdot 26$ & $11 \cdot 25$ & $28 \cdot 19$ \\
\hline${ }^{*} 53, \mathrm{xy}, \mathrm{t}$, & 4 & 331 & 29.91 & 9.06 & 35.48 \\
\hline$* 53, x y, t_{3}$ & 5 & 326 & 34.05 & $17 \cdot 18$ & 38.68 \\
\hline $51, x y, t_{1} t_{2} t_{3}$ & 3 & 332 & $10 \cdot 84$ & 5.42 & $11 \cdot 15$ \\
\hline
\end{tabular}

* Data from Chapman \& Bruère (1975).

† Data from this study and that of Chapman \& Bruère (1975).

The segregation pattern of the progeny produced by the matings of $51, \mathrm{xy}_{1}, \mathrm{t}_{1} \mathrm{t}_{2} \mathrm{t}_{3}$ rams and ewes of normal karyotype $(2 n=54)$ is given in Table 4 . There was a significant deviation from the expected $1: 1: 2: 2: 1: 1$ ratio of the products because of a significant deficit of $52, \mathrm{t}_{1} \mathrm{t}_{3}$ and $53, t_{2}$ progeny and a surplus of 54 progeny. The segregation pattern of the euploid secondary 
spermatocytes from the triple heterozygous rams (Table 5) also showed a significant deviation from the expected segregation ratio of the products, with a deficit of $25, \mathrm{t}_{1} \mathrm{t}_{3}$ figures and a surplus of 27 figures being observed.

Table 4. Numbers of progeny with respective chromosome number recorded from matings of triple heterozygous rams and 83 ewes of normal karyotype

\begin{tabular}{llllllll}
\hline Karyotype & $51, \mathrm{t}_{1} \mathrm{t}_{2} \mathrm{t}_{3}$ & $52, \mathrm{t}_{1} \mathrm{t}_{3}$ & $52, \mathrm{t}_{2} \mathrm{t}_{\mathbf{x}}$ & $53, \mathrm{t}_{\mathbf{x}}$ & $53, \mathrm{t}_{2}$ & 54 & Total \\
\hline $\begin{array}{c}\text { Expected } \\
\text { numbers }\end{array}$ & $10 \cdot 375$ & $10 \cdot 375$ & $20 \cdot 75$ & $20 \cdot 75$ & $10 \cdot 375$ & $10 \cdot 375$ & 83 \\
$\begin{array}{c}\text { Observed } \\
\text { numbers }\end{array}$ & 10 & 3 & 24 & 24 & 4 & 18 & 83 \\
\hline
\end{tabular}

$\chi_{5}^{2}=13.50 ; 0.01<P<0.02(1: 1: 2: 2: 1: 1$ ratio $)$.

Table 5. Number of euploid $(\mathrm{NF} / 2=30)$ metaphase II figures with respective chromosome number recorded from the triple heterozygous rams

\begin{tabular}{llllllll}
\hline Karyotype & $24, \mathrm{t}_{1} \mathrm{t}_{2} \mathrm{t}_{3}$ & $25, \mathrm{t}_{1} \mathrm{t}_{3}$ & $25, \mathrm{t}_{\mathbf{x}} \mathrm{t}_{2}$ & $26, \mathrm{t}_{\mathrm{x}}$ & $26, \mathrm{t}_{2}$ & 27 & Total \\
\hline $\begin{array}{c}\text { Expected } \\
\text { numbers }\end{array}$ & 35.875 & 35.875 & 71.75 & 71.75 & 35.875 & 35.875 & 287 \\
$\begin{array}{c}\text { Observed } \\
\text { numbers }\end{array}$ & 35 & 14 & 72 & 74 & 40 & 52 & 287 \\
\hline
\end{tabular}

$\chi_{5}^{2}=19.96 ; P<0.01(1: 1: 2: 2: 1: 1$ ratio $)$.

\section{Discussion}

It is seen from Table 1 that, as previously reported for homozygous translocation sheep and normal sheep (Chapman \& Bruère, 1975), no hyperhaploid cells were found in the 84 cells evaluated from the 3 normal rams. In the present study only one cell from the normal rams was found to have 29 chromosome arms. This cell may not have been a true aneuploid secondary spermatocyte but rather the result of a chromosome loss due to lagging at the first anaphase. This and previous evidence suggest that there are either very few or no aneuploid secondary spermatocytes produced during spermatogenesis by either the normal ram or homozygous translocation-carrying rams.

The data from Table 2 show that there was a considerable variation in the levels of aneuploid metaphase II frequency between the 3 triple heterozygous rams. This variation ranged from $5 \cdot 81-2 \cdot 33 \%$ in Ram B $47 / 48$ to $16 \cdot 6-6 \cdot 6 \%$ in Ram B $111 / 77$, the mean level being $5.42 \%$ and is consistent with the individual variations in aneuploid metaphase II frequencies which have been found in all the single heterozygous rams studied so far (Chapman \& Bruère, 1975; Long, 1978). This is similar to results from comparable studies on translocation-carrying mice (White \& Tjio, 1967; Cattanach \& Moseley, 1973; White, Crandall, Raveche \& Tjio, 1978).

The mean level of aneuploid frequency in the triple heterozygote rams was significantly higher than the zero level found in the homozygous $\left(t_{1} t_{1}\right.$ and $\left.t_{3} t_{3}\right)$ and normal rams (Table 3 ). Therefore, as with the single heterozygotes (Chapman \& Bruère, 1975), triple heterozygosity for the Robertsonian translocations is a factor leading also to the increased frequency of aneuploid secondary spermatocytes. However, the level found in the triple heterozygotes was comparable to the levels reported for single heterozygous rams (Chapman \& Bruère, 1975; Logue, 1977; Long, 1978) and was unexpectedly not even approximately equal to the sum of the individual levels in the singly heterozygous animals, which were $6 \cdot 90 \%-13 \cdot 56 \%\left(t_{1}\right), 9 \cdot 23 \%-13 \cdot 11 \%\left(t_{2}\right)$ and $16.5 \%-20 \cdot 20 \%\left(t_{3}\right)$. In this respect the multiple translocation-carrying sheep appear to differ from the tobacco mouse (M. poschiavinus) hybrids (Cattanach \& Moseley, 1973) but are 
similar to the artificially evolved triple translocation-carrying mouse heterozygotes described by White et al. (1978). The individual variation in aneuploid spermatocyte frequency and the lack of evidence for an increase in aneuploid spermatocyte frequency in triple heterozygous rams further suggest that the rate of non-disjunction is genetically determined and is not a function which can be attributed entirely to the presence of translocations per se.

There was a significant excess of normal secondary spermatocytes and a deficit of $t_{1} t_{3}$ secondary spermatocytes in the triple heterozygotes as well as a significant excess of normal progeny and a deficit of $t_{1} t_{3}$ progeny from the matings of the triple heterozygous rams and normal ewes. Again, this differs from the results for triple heterozygous mice described by White et al. (1978) in which the segregation products in the embryos were balanced and demonstrated no preferential segregation of the translocations. However, it is probably premature, with the limited data available, to speculate on the significance of this correlation in sheep. In earlier meiotic studies, a significant excess of normal balanced secondary spermatocytes was found in single heterozygous rams (Chapman \& Bruère, 1975; Long, 1978) but subsequent mating data demonstrated a balanced segregation pattern (Bruère \& Ellis, 1979). Although it is possible that a process of cell selection during spermatogenesis results in the production of gametes in proportions which are significantly different from the expected ratio $(1: 1: 2: 2: 1: 1)$, it has previously been suggested by Ortavant (1958) and Roosen-Runge (1973) that the chromosomally abnormal cells in the ram and translocation-carrying rams (Bruère, 1974a; Chapman \& Bruère, 1975) are removed before maturation is complete. Further studies on the other multiple translocation-carrying rams might indicate that certain cells are selected against or degenerate during spermatogenesis.

We gratefully acknowledge the technical assistance of Karen Armitage, and the Wellcome Trust for support of this project.

\section{References}

Baranov, V.S. \& Dyban, A.P. (1976) Prezygotic selection of male gametes in laboratory mice. Tsitologiya 18, 556-559.

Bruère, A.N. (1974a) The segregation patterns and fertility of sheep heterozygous and homozygous for three different Robertsonian translocations. $J$. Reprod. Fert. 41, 453-465.

Bruère, A.N. (1974b) The discovery and biological consequences of some important chromosome anomalies in populations of domestic animals. Proc. lst Wld Congr. Genet. appl. Livestock Prod., Madrid, pp. 151-175. Graphical Orbe, Madrid.

Bruère, A.N. \& Chapman, H.M. (1974) Double translocation heterozygosity and normal fertility in domestic sheep. Cytogenet. Cell Genet. 13, 342-351.

Bruère, A.N. \& Ellis, P.M. (1979) Cytogenetics and reproduction of sheep with multiple centric fusions (Robertsonian translocations). J. Reprod. Fert. 57, 363-375.

Bruère, A.N. \& McLaren, R.D. (1967) The idiogram of the sheep with particular reference to secondary constrictions. Can. J. Genet. Cytol. 9, 543-553.

Cattanach, B.M. \& Moseley, H. (1973) Non-disjunction and reduced fertility caused by the tobacco mouse metacentric chromosomes. Cytogenet. Cell Genet. 12, 264-287.
Chapman, H.M. (1974) Some aspects of meiosis in normal and Robertsonian translocation-carrying rams. Ph.D. thesis, Massey University, New Zealand.

Chapman, H.M. \& Bruère, A.N. (1975) The frequency of aneuploidy in the secondary spermatocytes of normal and Robertsonian translocation-carrying rams. J. Reprod. Fert. 45, 333-342.

Gropp, A., Tettenborn, U. \& Von Lehmann, E. (1970) Chromosom envariation von Robertson'schen Typus bei der Tabakamaus, $M$. poschiavinus und ihren Hybriden mit der Laboratoriumsmans. Cytogenetics 9, 9-27.

John, B. \& Freeman, M. (1975) Causes and consequences of Robertsonian exchange. Chromosoma 52, $123-136$.

Kurnit, D.M., Brown, F.L. \& Maio, J.J. (1978) Mammalian repetitive DNA sequences in a stable Robertsonian system. Characterization, in situ hybridizations, and cross-species hybridizations of repetitive DNAs in calf, sheep and goat chromosomes. Cytogenet. Cell Genet. 21, 145-167.

Logue, D.N. (1977) Meiosis in the domestic ruminants with particular reference to Robertsonian translocation. Ann. Genet. Sel. Anim. 9, 493-507.

Long, S.E. (1978) Chiasma counts and non-disjunction Downloaded from Bioscientifica.com at 04/26/2023 08:06:19AM via free access 
frequencies in a normal ram and in rams carrying the Massey I $\left(t_{1}\right)$ Robertsonian translocation. J. Reprod. Fert. 33, 353-356.

Ortavant, R. (1958) La cycle spermatogenetique chez le belier. Thesis, University of Paris.

Roosen-Runge, E.G. (1973) Germinal-cell loss in normal metazoan spermatogenesis. J. Reprod. Fert. 35, 339-348.
White, B.J. TJio, J.H. (1967) A mouse translocation with 38 and 39 chromosomes but normal N.F. Hereditas 58, 284-296.

White, B.J., Crandall, C., Raveche, E.S. \& Tjio, J.H. (1978) Laboratory mice carrying three pairs of Robertsonian translocations: establishment of a strain and analysis of meiotic segregation. Cytogenet. Cell Genet. 21, 113-138.

Received 15 September 1980 